\title{
The politics of diaspora and the morality of secularism: Muslim identities and Islamic authority in Mauritius
}

\author{
PATRICK EISENLOHR Washington University
}

\begin{abstract}
Previous work on inter-ethnic coexistence in Mauritius has portrayed secularism as the only possible site of the national, which is at the same time described as clearly separated from religious traditions. In contrast, focusing on understandings of secularism among Mauritian Muslims in the context of a politics of diasporic 'ancestral cultures', this article analyses secularism as a field of morality which is inseparable from questions of religious reform and authenticity. The discussion of ethnographic material from Mauritius suggests that the opposition between secularity and religiosity should be treated as a productive tension rather than a liberal antinomy.
\end{abstract}

Recent anthropological studies of diasporas have highlighted their transnational orientation towards multiple political locations, which frequently places diasporas at odds with a prevailing global political order. Diasporic identifications do not, however, always stand in tension with national belonging. Indeed, the public performance of such identifications in ethnic holidays, religious festivals, ethnic cultural centres, and the state-sponsored cultivation of ancestral languages is one of the ways in which full membership in a Mauritian nation is claimed and demonstrated (cf. Eriksen 1994). Mauritians, who publicly celebrate a continuing memory of their origins in another part of the world through such activities, often experience diasporic belonging through the prism of purist, clearly demarcated, and officially recognized 'ancestral cultures'. These two themes come together in a hegemonic sense of cultural citizenship according to which Mauritians are primarily conceived as subjects with origins elsewhere and ongoing commitments to traditions whose diasporic character is highlighted (Eisenlohr in press). Although in the 1970 s and early 1980 s a political movement promoted a new Mauritian nationalism privileging locally created cultural forms, in particular the dominant local vernacular language Mauritian Creole as a base for Mauritian postcolonial nation-building, Mauritian state institutions clearly emphasize support and recognition of cultural traditions perceived as diasporic. ${ }^{1}$ That is, the cultural politics of the Mauritian state privileges 'ancestral cultures', experienced as diasporic insofar as their origins elsewhere are publicly emphasized, over those traditions which can be constructed as indigenous, such as the practice of Mauritian Creole. ${ }^{2}$ At the same time, 
since these recognized 'ancestral cultures' circumscribed by the state are largely identified with different religious traditions, the Mauritian politics of diaspora raises the question of equitable coexistence in an officially multi-religious polity.

In this article, I investigate how a politics of diaspora privileging the performance of 'ancestral cultures' centred on religious traditions is predicated on a particular understanding of secularism. In this I recognize the close interrelationships between the advent of a modern nation-state based on the conception of a society subject to secular techniques of social transformation and the concept of 'religion' as a separate sphere of life distinct from politics, society, and law (Asad 2003). Religious traditions in the Mauritian case become the object of modern secular statecraft, to be managed as potentially dangerous forces while at the same time mobilized for the good of society. This is because they are considered indispensable for providing the kind of self-discipline among citizens that enables toleration and peaceful coexistence between members of different religious communities in a common polity.

In what follows, I problematize the antinomy between the secular and the religious by investigating local understandings of secularism among Mauritian Muslims. While others have suggested that modern concepts of 'religion' are an outcome of the rise of secular perspectives on social life (Asad 2003: 190-3), I argue that the relationship between secularity and religion should be seen as a productive tension in which the religious crucially shapes secular practices and visions of social life. Indeed, central symbols and ideologies of secularism may be mediated through the mystical and the religious (Navaro-Yashin 2002: 188-203). While parallels between the engagement with, for example, secular symbols of nationality and what is readily recognized as religious practice have frequently been remarked, my concern here is morality as a sphere in which the secular and the religious are in a dialectical tension. Secularism in Mauritius is constituted as a field of morality focused on the shaping of dispositions conducive to coexistence, which are never separate from those practices and traditions aimed at shaping pious subjects. In particular, I seek to show how a regime of state neutrality towards religious traditions which at the same time draws on 'moral values' as furthering toleration and peaceful coexistence among religiously diverse citizens becomes entangled in the cause of religious reform. Focusing on Muslim debates about the authenticity of different Islamic traditions, I demonstrate how such debates not only are conducted in terms of a genealogical logic of relating Islamic practice to scriptural sources via reliable chains of interlocutors but also address the Mauritian state's politics of mobilizing 'ancestral' religious values in order to shape responsible citizens suitable for successful coexistence with others in an officially plural society. In other words, the Mauritian politics of diasporic 'ancestral cultures' is based on a particular understanding of secularism, which in turn becomes a driving force in debates about religious reform and authenticity among Mauritian Muslims.

\section{The governmentality of secularism}

The main supporters of this particular form of Mauritian nationalism according to which membership in the nation and the intense cultivation of diasporic links are not only compatible, but actually reinforce each other, are the middle class among the Hindu majority of Mauritius ( 52 per cent), particularly those of North Indian origin (41 per cent). The latter dominate Mauritian politics and state institutions. Mauritius is singular among locations in the South Asian diaspora since almost 70 per cent of its population is of Indian origin. Among Indo-Mauritians, Mauritian Muslims are 
recognized as a separate community in the constitution, comprising 17 per cent of the population of 1.2 million. As is the case for Hindus, for Muslims religious traditions are considered as largely coterminous with the 'ancestral culture' through which their place in a Mauritian nation is defined and legitimized, thereby problematizing the boundaries between religious traditions and national identity. The vision of Mauritian national identity drawn in this politics of ancestral cultures is above all an ensemble of ancestral and diasporic religious traditions, in which the continuing visibility of boundaries between ethno-religious communities in national politics as well as in everyday life does not contradict the idea of coexistence.

Mauritian state institutions encourage the cultivation of diasporic 'ancestral cultures' in the context of a wider Mauritian political ideal of 'unity in diversity' and ethno-religious even-handedness. These 'ancestral cultures' centred on religious traditions were shaped and circumscribed under colonialism, and their cultivation is favoured because they are believed to be sites of 'moral values' to be instilled in Mauritian citizens. In a Gandhian discourse, such moral values as part of religious traditions are presented as providing a counterweight to forces of agonistic competition and materialism held to be prevalent in modernizing societies. According to this perspective, they orientate citizens towards tolerance and coexistence. Thus, the Mauritian state generously subsidizes the activities of religious organizations, massively assists in the public celebration of religious holidays and pilgrimages, provides for the teaching of ancestral languages in state schools, and substantially contributes to the establishment of 'cultural centres', which in most cases have an openly ethnic-religious agenda for all those with recognized claims on an 'ancestral culture. ${ }^{3}$

As such, Mauritian 'unity in diversity', understood as neutrality of the state towards religion, is at odds with projects of secularism centred on an emphatic separation of state and religious institutions. Examples of the latter would be French politics of laïcité aiming to exclude religious symbols and discourse from political debate and state institutions (Baubérot 2000), the legal doctrine of a 'wall of separation' between state and religious institutions in the United States, or more aggressive forms of secularism as a dismantling of religious institutions by the state and placing those which remain under strict state control, as in Turkey (Göle 1997). Mauritian secularism, however, has much in common with the politics of secularism in India. As in India, the Mauritian population is officially divided into 'communities', with religion being the most prominent criterion of division, ${ }^{4}$ and religious communities and their symbols are expected to be very visible in the public sphere. Citizenship is thus qualified by religious membership. As religious belonging is conceived as a primary identification for most citizens, politics should be ideally guided by the equal recognition of all religious traditions and neutrality towards them.

Analyses of Indian secularism have identified two important themes in discourses of India as a secular nation. First, an antagonism between an educated secular elite and the uneducated masses is highlighted. Here it becomes the task of the secular elite to control the religious passions of the masses in order to enable peaceful and equitable coexistence (Chatterjee 1995) and to enforce a separation between 'culture', located in traditional 'communities', and 'politics' (Hansen 2000). In particular, Western-style education is considered to turn subjects into responsible and rational Indian citizens. A second theme is the Gandhian distinction between authentic and benign 'faith' and 'perverted', ideologized religion manifest in violent communalism geared towards a maximizing of political power. While the former shapes citizens towards tolerance and 
peaceful coexistence in a spirit of 'true' religiosity and moral rectitude, the latter, encouraging hatred and intolerance, is the bane of a plural society. In contrast to those emphasizing the importance of secular and Western-style education for countering religious passions, proponents of this Gandhian position see the destruction of 'genuine' religious tradition among the populace in the name of a secularist politics of modernization as the chief culprit behind intercommunal violence in contemporary India. Along these lines, Ashis Nandy (1990) has called for the recovery of presumably authentic religious traditions of popular faith in India which favour peaceful coexistence in order to fight violent Hindu nationalism. According to Nandy, Hindu nationalism represents an instance of 'perverted religion' (1998: 284) resulting from the 'contest for the allegiance of the decultured, the atomised and massified', who exemplify the Indian middle class and urban India in general (1998: 292).

The Gandhian rhetoric of 'true' religiosity as fostering mutual respect and peaceful coexistence is also central to Mauritian understandings of secularism, which is often portrayed as engaged in a combat against a destructive communalism (kominalis in Mauritian Creole) drawing on religious identifications. ${ }^{5}$ Mauritian understandings of secularism build on a related colonial genealogy and are also centred on the principle of state neutrality towards religious traditions rather than on an avoidance of state intervention in religious affairs or of the use of religious imagery and discourse in politics. Nevertheless, compared to the modernist-statist theme in Indian discourses of secularism, the relationship in the regulation of the religion-politics nexus between an educated elite of state functionaries and the masses is conceived in an almost inverse way. Instead of assuming that the masses are easily consumed by religious passions and continue to act and identify as religious communities, state discourse in Mauritius highlights an apprehension of a decline of religious traditions and the moral values supposed to be enshrined in them in a process of rapid modernization and development. Accordingly, the task of state institutions is to ensure that 'ancestral cultures', as sites of moral values, are promoted so as to combat the social anomie and moral corruption potentially endangering the 'social fabric' of Mauritian society. As such, Mauritian secularism can be understood as a strategy of governmentality, a technique of regulating social life in the context of controlling the welfare of a population (Foucault 1991). This strategy is different from secularism as a scientific mode of governance in India as it has been analysed by Chatterjee (1995). The particularity of Mauritian secularism is that it ostensibly draws on a Gandhian critique of modernization, which is then paradoxically recast in terms of a project of modern governance.

Armoogum Parsuraman, minister of education and arts and culture from 1984 to 1995, repeatedly stressed that the Mauritian state seeks to fight the negative consequences of rapid economic modernization through the teaching of ancestral cultural values in the context of ancestral language instruction, which in turn is inseparable from promoting particular ancestral religious traditions (Parsuraman 1988). Addressing a Muslim audience on the occasion of the twentieth anniversary of the National Urdu Institute in 1990, the minister asserted that the promotion of ancestral languages was the 'leitmotiv of my Ministry' and declared: 'In tune with the policy of our Government, my Ministry has left no stone unturned to promote the various cultures of our pluri-ethnic society through all kinds of possible assistance. ${ }^{6}$ Also, in a message to the almost exclusively Muslim audience present at the Second World Urdu Conference held in Mauritius in August 2003, Prime Minister Anerood Jugnauth repeated the official rationale for the promotion of ancestral religious traditions: 
The cultural fabric of our society is consolidated by the rich ancestral values and traditions of our Urdu-Speaking compatriots ... Government will continue to provide its unflinching support to the endeavours of the various religious and socio-cultural organizations geared towards the consolidation of our cultural fabric. Let us join hands together to bring national unity, peace and harmony in our country. This is a sine qua non for achieving progress, happiness and brotherhood. ${ }^{7}$

In similar terms Jugnauth hailed the foundation of a Ramayana Centre run by an alliance of Mauritian and Indian Hindu organizations, some with Hindu nationalist ties, on a plot of land donated by the Mauritian state, since it [is] very important to perpetuate human values, particularly in the present context when crimes have increased, family breakups and divorces are frequent and moral commitment has lost its meaning. ${ }^{8}$ He stressed that only 'socio-cultural organizations', which in Mauritian public discourse refer to religious organizations with an ethnic agenda, 'can in a real sense be the answer to today's social problems', while the Ramayana Centre 'would play a pivotal role for the moral and social uplift of the society at large.' Accordingly, such moral values, supposedly inherent in 'ancestral cultures' and associated ancestral languages, enable Mauritians to live spiritually and economically fruitful lives in solidarity with others. While they are held to be vital in their capacity to control an unfettered competition for material goods and benefits between citizens, they are thought of as increasingly scarce under conditions of rapid economic transformation, technical development, and increased prosperity. Western-style education, which the great majority of Mauritians now undergo, is believed insufficient to instil the spirit of coexistence and respect for the other which can be provided only by the values of 'ancestral' religious traditions.

\section{Secular politics and religious authenticity}

In contrast to the Indian politics of secularism with its deep ambivalence about the social effects of religious traditions on a 'composite' society, official Mauritian state ideologies portray the social and political consequences of an intense cultivation of religious traditions in more optimistic terms. When former Prime Minster Anerood Jugnauth made his well-known declaration that throughout his long years as a prime minister 'in politics and statecraft the Ramayana has been my greatest ideal' ${ }^{10}$ and that his economic policies were guided by the principles of 'bhakti and shakti, ${ }^{11}$ he did not consider himself making a 'communalist' statement openly favouring Hindu religious traditions and political interests over others. ${ }^{12}$ Instead, he presented himself as being guided by perennial values enshrined in the Ramayana and its teachings, values also immanent in other traditions and thought to enable just government and equitable coexistence. As a consequence of this identification of 'moral values' with peaceful coexistence, secular politics in Mauritius is often couched in a discourse on religious tradition.

Concern about moral values inhabiting 'ancestral cultures' cannot be de-coupled from concerns about religious reform and authenticity. One of the consequences of such strategies of shaping citizens suitable for coexistence in an officially plural society through ancestral moral values is a heightening of conflict about the authenticity of such ancestral traditions. This is because ancestral religious traditions deemed authentic also play a central role in moral debates about equitable coexistence in an officially multi-religious polity. Here the Gandhian separation of presumably genuine religiosity and destructive religious communalism is of great importance for explaining a link 
between religious reform, authenticity, and secularism. Secularism in the Mauritian context often means supporting those ancestral traditions which are authentic representatives of a Gandhian 'true' religiosity. Both representatives of state institutions and many Mauritians in everyday contexts emphasize that only those ancestral traditions deemed authentic and validly founded have the power to shape Mauritian national subjects in a spirit of peaceful and equitable coexistence. Among Mauritian Muslims such concerns about authentic and inauthentic dimensions of religious traditions have intensified debates about who speaks for authentic Islam in Mauritius. However, in asserting their superiority over exponents of other Islamic traditions, it is not enough for participants in these debates to claim to be better Muslims than others or to insist that their standpoints are more reliably connected to sources of Islamic authenticity such as the Qur'an or the Hadith (the authoritative record of the words and doings of the Prophet and his companions). They must also situate themselves in relation to a discourse of coexistence and the shaping of Mauritian citizens suitable for that task. That is, debates about Islamic tradition are intimately linked to Mauritian politics of secularism. 'Ancestral' religious traditions such as Islam constitute vital components of national identity and are also thought to play a key role in ensuring successful coexistence among Mauritius's citizens. Although often presented as far removed from politics, the theme of 'true' religiosity is central to the discourse of coexistence. 'Ancestral culture' therefore erases the boundaries between 'private' or community-based religion and the politics of nationhood.

\section{Muslim identities and Islamic traditions in Mauritius}

The establishment of a Muslim community in Mauritius is above all the result of the indenture system, through which hundreds of thousands of Indian labourers were exported to work on sugar plantations in other parts of the British Empire, Mauritius being the destination receiving the single largest number of migrants between 1834 and the First World War (Carter 1995). Nevertheless, a small number of Indian Muslims had already arrived under French colonial rule (1715-1810) while, as early as the 1840s, free trader-immigrants of Muslim Gujarati background had begun migrating to Mauritius. Supported by their capital and intense continuing links to India, the Gujarati traders emerged as a social elite among the Indian and Indo-Mauritian population and became the principal founders and promoters of Islamic institutions on the island (Kalla 1987). Thus, even though primarily of North Indian indenture background, Muslims in Mauritius were from the beginning characterized by important ethnic and class differences, which had a major impact on the local practice of Islamic traditions and the formation of political identities among Muslims in Mauritius.

The Kutchi Memons, a trader caste originally from Gujarat but with dense networks throughout India and the Indian Ocean region, soon established themselves as the most economically successful of these Gujarati elites and also became central to the formation of an Islamic establishment of mosques, madrasas (religious schools), and links to Islamic institutions in India. The Memons in particular cultivated a close relationship with the tradition of the Sunni South Asian Ahl-e Sunnat va Jama'at ('People of the Prophet's way and the majority community', hereafter Ahl-e Sunnat), which in the 1920 and 1930 became the predominant form of institutionalized Sunni Islam in Mauritius and is locally known as the Sunnat Jama'at. ${ }^{13}$ The Ahl-e Sunnat, also known in South Asia as the Barelwi tradition, is one of the reformist traditions which emerged 
in nineteenth-century Indian Islam. In contrast to other, more familiar reformist traditions of Indian Islam, such as the school of Deoband, the Ahl-e Sunnat is known for its great emphasis on practices of intercession (Sanyal 1996). These entail the veneration of Sufi saints and a particular understanding of the Prophet Muhammad defined through the doctrine of hazir-o nazir (present and observant), according to which the Prophet continues to have a spiritual presence manifest as pure light (nur-e muhammadi). Following this tradition, the Prophet's powers of intercession with God can be appealed to by means of the recitation of poetry in praise of the Prophet ( $\left.n a^{c} t\right)$ during ritual gatherings known as mawlud or mahfil-e mawlud as well as through the collective recitation of Urdu panegyric poetry and Arabic litanies in praise of the Prophet (darud), which is known as salam and performed after the Friday prayers.

Among Muslims, Memon dominance enabled by their wealth and connections to centres of Islamic learning in India had gone hand in hand with local control over the most important Islamic institutions. Beginning in the 1950s two major changes brought about challenges to this hegemony. First, Muslims of indenture (Kalkattiya) background experienced the beginnings of wider social mobility, as some Kalkattiya families attained middle-class status via new opportunities for higher education in India and Britain. This led to the formation of a steadily growing class of professionals of indenture background who were less inclined to accept the continued social and political dominance of the Memons. Second, representatives of the school of Deoband started to establish themselves in greater numbers in Mauritius. The Sunni Surtees, another Gujarati trader community in fierce competition with the Memons, initially played a key role in introducing the Deobandi tradition to Muslims in Mauritius. In 1954 the Surtees completed the construction of their Markazi Mosque in Port Louis, which became a centre for an intensifying relationship between the Surtees and Deobandi scholars and preachers from India. It came to function as a social counterweight to the established main Jummah Mosque of the capital, run by the Memons. Most importantly, the Deoband-affiliated Tablighi Jamaiat, the single most powerful transnational Islamic missionizing movement in the world today, arrived in Mauritius in the late 1950s. ${ }^{14}$ In Mauritius, the Tablighis were initially closely linked to the Surtee community, but they were also very successful in attracting a steadily growing number of Muslims of indenture background (see also Hollup 1996). They thus emerged as a formidable challenge to the dominance of the Sunnat Jamaiat and their local Memon patrons to the extent that today the number of their followers in Mauritius is commonly said to approach the numbers of the diminished Sunnat Jamaiat constituency.

\section{Urdu and Arabic as Muslim 'ancestral languages'}

A central part of a Mauritian cultural politics of 'unity in diversity' centred on the promotion of diasporic 'ancestral cultures' is the teaching and official valorization of socalled ancestral languages (lang ban anset in Mauritian Creole); these are Hindi, Urdu, Tamil, Telugu, Marathi, Arabic, and Mandarin. The 71 per cent of students in Mauritian government or government-assisted schools who do not belong to the Christian 'general population' are automatically assigned from primary level to the study of one of these languages. Selection and assignment to the study of a particular ancestral language is performed according to the students' ethnic-religious background, which school authorities routinely identify by the students' names and locally known ethnic affiliations. Ancestral languages are never used in everyday life and were in most cases 
not even current among immigrating ancestors of the people claiming them as their ethnic property. However, they are considered essential mediators and components of official 'ancestral cultures'. Since the 'ancestral cultures' of the Indo-Mauritian population are largely defined by religious traditions, the authenticity of the respective ancestral languages is above all measured by their perceived significance for such traditions. Enabled by linguistic ideologies (Woolard \& Schieffelin 1994) constructing presumably self-evident links between particular linguistic and religious traditions, those cultivating an officially recognized ancestral language strengthen their claims on membership in a Mauritian nation conceived above all as an ensemble of diasporic traditions. Official ancestral languages represent a key instance of state intervention in religious traditions aimed at mobilizing the latter for a project of secularism focused on state neutrality towards such traditions while simultaneously promoting them to strengthen social and political cohesion through moral uplift.

Nevertheless, the significance and authenticity of ancestral languages has sometimes become a focus of conflict among Mauritians, especially among Mauritian Muslims, who represent the only Mauritian ethnic community with two officially recognized ancestral languages. The contest between promoters of Urdu and Arabic as ancestral languages for Mauritian Muslims is in turn closely related to the conflict between the supporters of the previously hegemonic Sunnat Jamaiat (Barelwi) tradition and the more recently expanding Tablighi movement, the main representatives of the Deobandi tradition in Mauritius. Although none among the contestants openly declare themselves to be against Arabic or Urdu, respectively, Mauritian students in government or government-assisted schools can only study one ancestral language, which for Muslim students amounts to a choice between Urdu and Arabic. Parents who are affiliated with the Sunnat Jamaiat are most likely to demand Urdu to be taught as ancestral language to Muslim students, while those affiliated with the Tablighi movement or other Deoband-associated traditions tend to favour the study of Arabic over Urdu. The choice between Arabic and Urdu, imposed as a matter of prioritization in the context of a Mauritian cultural policy of 'ancestral cultures' and ancestral languages, is thus informed by language ideologies centred on perceptions of the relative link of these two languages to places and traditions of Islamic authority. Those drawing a positive image of the place of Indo-Pakistan as a site of Muslim life and Islamic authenticity also argue for the primacy of the study of Urdu for what they regard as the 'Islamic culture' of Mauritians of Indian origin. In contrast, those who are suspicious of the authenticity of South Asian Islamic practice and who view Mauritian Islamic traditions as being in serious need of purification and reform tend to favour the study of Arabic over Urdu, considering the former as essentially connected to what they see as the original sources of Islam. Although it was impossible for followers of the Sunnat Jamaiat and Urdu teachers to argue against the teaching of Arabic per se, they pointed out that standard Arabic was difficult to learn and that, unlike the case with Urdu, the great majority of Mauritian Muslims would never gain any meaningful access to the language. The opponents of Arabic as an ancestral language also argued that the perpetuation of authentic Islamic traditions in Mauritius would depend on the cultivation of Urdu, given the Indian background of Mauritian Muslims. They claimed that the introduction of Arabic would result in a decline in the knowledge of Urdu and that Arabic would never be properly learned by the great majority of students. As a consequence, 'Islamic culture' in Mauritius would be undermined by a choice of Arabic as the 'ancestral language' of Mauritian Muslims. 


\section{Debating Islamic tradition in the context of secularism}

What are the local meanings and practices of secularism in Mauritius, where the politics of secularism are based on an ideal of state neutrality towards a plurality of officially recognized religious traditions and where discourses of secularism often draw on moral values in calling for equitable coexistence? Among Mauritian Muslims, this ethos of coexistence is most often talked about in a language of religious reform and authenticity and is also mobilized for claims of superiority over competing interpretations and practices of Islam. At the same time, Muslim debates about religious reform are linked to the politics of nationhood and coexistence because the authenticity of Muslim 'ancestral culture', the subject of these debates, underpins Muslim membership in a Mauritian nation.

Given the ongoing rivalry especially between Barelwis and Deobandis, the authenticity of Islamic traditions is a very contested issue in Mauritius. At the same time, Mauritian Muslims link the question of religious authenticity to the issue of diasporic origins in different ways. Some privilege South Asia as an authentic centre of Islamic traditions, others promote a presumably 'pure' Islam, which they portray as directly connected to centres of authority in the Arab world. The rhetoric of the latter approach, however, can also be situated in Indian traditions of Islam dating back to at least the eighteenth century. Here Muslim debates in Mauritius closely resemble similar disputes in other parts of the Muslim world, where proponents of a return to pristine orthodoxy are confronted with others who insist on the value of those Islamic practices which have grown up in their communities over hundreds of years. However, the specificity of these debates in Mauritius is that they are more closely connected to issues of coexistence and secularism in a religiously and ethnically plural society than in many other locales where such debates are unfolding. This is because in arguing about the authenticity of Islamic traditions and Urdu or Arabic as ancestral languages, the participants in these debates also construct relationships to state-sponsored and recognized Muslim 'ancestral culture' and therefore to secularism as a moral project.

There are a fair number of people claiming to be Muslim authorities and spokesmen for all Muslims in Mauritius, each asserting to represent authentic Islam according to a genealogical logic of faithful transmission. Followers of the Deobandi tradition advocate a purified Islam which combines religious reform and the fight against social problems such as crime, drugs, and family disintegration. They justify their claims not just in terms of an internal debate about authentic Islamic tradition but also by addressing the politics of secularism, indicating the benefits that their project would contribute to Mauritian society as a whole through shaping more morally responsible and educated citizens. At the same time, in a discourse of 'anti-politics' (Hansen 1999: 50; 2000: 257), they deny that their project has any political dimensions but stress its contribution to the presumably perennial and sublime moral and spiritual values which enable Mauritian coexistence.

Muhammad Dahal, the head of the Qur'an House in the central town of Rose-Hill, considered that the Muslim community was lacking knowledge of proper Islamic conduct before the establishment in 1959 of the Islamic Circle (of which the Qur'an House is an offshoot). The Islamic Circle was co-founded by a Pakistani follower of Mawlana Abu al-A'la Mawdudi, the founder of the Jamaiat-e Islami, one of the pioneering movements of modern Islamism which also traces its origins to the tradition of Deoband. Dahal viewed the particular Deobandi tradition he stands for as superior not only because of what he claimed to be its greater scriptural authenticity, but also 
for its stress on education and modernization. He advocated a purified Islam that motivates Mauritian Muslims to become educated and moral citizens:

Before 1959 there was no awareness that Islam is a complete way of life, people just thought that it is enough to practise prayer and rituals. Islam does not stop at prayer. Young people these days are more dynamic and very avid to learn. They want to go to the sources of Islam directly. There is still the influence of the Indian ancestral culture, but it will disappear over time with increased education.

Dahal effectively challenged the government-sponsored construction of official 'ancestral cultures' for different ethnic groups in Mauritius. 'Ancestral cultures' are typically represented under the assumption that religious traditions and other dimensions of such 'ancestral cultures' are largely indistinguishable. Dahal, on the other hand, argued that the 'ancestral culture' of Indo-Mauritian Muslims and their authentic religious tradition are not only distinct, but even at odds with each other. Contrary to the widespread commitment to the reproduction or, as many in Mauritius say, 'preservation' of 'ancestral cultures', Dahal actually looks forward to their eventual demise across generations. Even though he himself represents a particular reformist tradition with a long historical trajectory in India, according to him the weakening of diasporic traditions from India would facilitate the emergence of authentic Muslims in Mauritius. He continued:

\footnotetext{
Young people today are more educated, they want to know the justification for certain rituals and practices. And then their elders can only answer that they have always done so. This is especially so with holding a mawlud, celebrating 'urs [anniversaries of the demise of saints] and praying at dargah [tombs of saints]. These practices have always been supported by the Jummah Mosque, but now young people can see for themselves that they have little to do with the Qur'an and the Sunna [the traditions of the Prophet]. Islam is above all about education, and in this we contribute to the mixture of cultures we have in Mauritius.
}

Here Dahal combined the themes of religious reform and the spread of education in a progressivist stance that goes hand in hand with his claim to contribute to the shaping of good citizens who are morally fortified but nevertheless 'modern'. The argument that education will inevitably lead to a rejection of practices deemed 'popular' and 'traditional' by many was also emphasized by a Pakistani imam who was trained in the Deobandi tradition and has resided in Mauritius for sixteen years. He is imam of a mosque in a town in the main urban zone of Mauritius and director of the dar-ul 'ulum (Islamic academy) attached to it:

Barelwis are becoming Deobandi, and not the other way around. Especially educated people who have studied about Islam, they cannot remain Barelwi. I have never seen a case where a Deobandi became a Barelwi, but the reverse is happening all the time.

An important part of this concern about education and religious reform often stressed by Deobandi leaders is the propagation of Arabic as the officially recognized 'ancestral language' instead of Urdu. According to them, knowledge of Arabic rather than Urdu would enhance knowledge of scriptural sources of Islam. Muhammad Dahal pointed out that 'we were the pioneers of the study of Arabic in Mauritius, and the first to demand the teaching of Arabic in public schools. And until today, teaching Muslims Arabic has remained one of our priorities'. When Dahal claimed that young people are less affected by the Indian cultural influence of their ancestors and want to 
access the 'sources' of Islam directly, he also had in mind the promotion of Arabic as an ancestral language in Mauritian schools and the teaching of Arabic offered by his own institution. Dahal supports state intervention in religion through the introduction of Arabic as a recognized ancestral language of Muslims in Mauritius. His claims about a reformist Islam shaping educated and progressive citizens who positively contribute to the 'mixture of cultures' in Mauritius are very much in line with the state's policy of securing equitable and peaceful coexistence through fortifying 'ancestral cultures' with their religious traditions.

A link between the struggle against social problems and religious reform was also stressed by Imam Beharry, a member of parliament and the imam of the Noor-e Islam mosque in the capital, Port Louis. He owns a small furniture factory and leads a modest lifestyle, and insisted that his MP allowance goes directly to the Noor-e Islam mosque. Beharry was a student of Abdul Rachid Nawab, a Hejazi scholar who arrived from the Arabian Peninsula in Mauritius in 1915 and lived there until his death in 1951. Imam Beharry has performed the hajj three times and umrah (the minor pilgrimage to Mecca) once but has never visited India or Pakistan. He told me:

\footnotetext{
When I give addresses in the mosque, I do not speak about rituals, festivals, which rituals should be held and when and how. But I address themes of actuality, speak against bad social practices. I have personally fought against drug dealers, I have attacked them in my addresses and Friday sermons, blocked their way in person in the street. Among the bad social practices is also the invocation of saints, which is the biggest illness of the Muslim community, such as the worship at tombs or yawmun nabi [celebrating the birthday of the Prophet] and holding mawlud. These illicit innovations cannot be found in the Qur'an or the Hadith and were invented so that people who were converting to Islam in India back then would continue to be attracted to Islam.
}

The imam thus drew a direct connection between social ills and 'bad' ritual practices. Accordingly, the task of religious reform and education also benefits Mauritian society at large. A presumably more authentic, purified Islam was also favoured by a public school Arabic teacher from a village in the South who had studied Arabic and Islamic Studies in Saudi Arabia, principally at the University of Medina, for seven years:

The main point is that we who follow tawhid ${ }^{15}$ strictly reject intercession between believers and God. Most of all, we do not call for the help of saints. The Qur'an is brutally clear in this respect. It is shirk [idolatry].

Like many other proponents of a purist approach to Islam, he viewed the spread of education and 'true Islam' as interlinked processes, a vision he extended to the teaching of Arabic, as well: 'These days people are more educated and can read the Qur'an themselves, in French and English. My mission in teaching Arabic is to enable people to learn to read the Qur'an directly'. The Tablighi Jamaiat are the most prominent promoters of the Deobandi tradition in Mauritius and they are especially known for promoting an 'anti-politics' aimed at a profound transformation of society through moral uplift. A lawyer in his office in the capital, who has been a long-standing member of the Tablighi Jamaiat, highlighted the non-confrontational attitude he believes should inform religious reform and purification, and stressed the importance of influencing others through personal example and practical commitment to an authentic Islam:

When we see a fellow Muslim who visits dargah, offers the salam after the Friday prayer and holds mawlud in his home, we do not criticize him. We don't think it is good to attack someone, we only 
want to persuade in a friendly and respectful way, because a good Muslim lives at peace with others. Teaching the good, and preventing the bad through patience and persuasion and becoming a better human being.

The lawyer added that many local Muslims had in the beginning been suspicious of the Tablighis with their purist approach to Islamic practice:

They think of a hidden purpose, a political agenda, but there is none, and they do not understand why. Some even suspect that we want an Islamic state. But we Muslims are a minority here and helping people to become better human beings means that they will live in peace with everybody else.

Despite this insistence on avoiding politics, the claim of turning people into morally improved and more peaceful persons through tabligh, the missionizing effort, invokes the Mauritian project of secularism in its stress on moral values promoting coexistence. The lawyer counted the study of Arabic instead of Urdu among the efforts that Muslims in Mauritius can undertake to purify themselves through a close following of the Qur'an and the Sunna, and Tablighi local circles frequently offer introductory Arabic classes on a neighbourhood level, alongside classes in basic Islamic studies conducted in Creole. The lawyer, himself of Gujarati origin, offered an additional genealogical explanation as to why he considers the study of Arabic to be preferable to learning Urdu: 'Gujaratis are very mixed with and close to the Arabs'.

To sum up, the cultivation of Arabic as an 'ancestral language' in Mauritius is presented by its supporters as part of a wider project of religious and moral reform which is justified not only in terms of greater authenticity within an Islamic tradition, but also as contributing to the production of morally grounded citizens capable of coexistence with others. In this, proponents of purist religious reform also claim that their demands are not only compatible with Mauritian secularism but actually support a secular project of coexistence through the promotion of authentic ancestral traditions inhabited by moral values.

Followers of the Sunnat Jamaiat in turn by no means accept being labelled as promoting a less authentic form of Islam. They rarely see a need for the reformist and purifying agenda of the Deobandis, arguing that the reproduction of good Mauritian Muslims depends on the cultivation of the Islamic traditions they see as having been brought by their ancestors from India, which they consider not at all deficient in scriptural authenticity. A student recently returned from studies at an Indian university rejected the idea that Islamic practices current in Mauritius are in need of substantial reform or that Mauritius should be considered a peripheral part of the Muslim world:

We may be far away from the Arab countries, but I do not feel cut off from Islam; I am not worried about that. This is because we are originally from India and we have preserved many of the traditions from there. For example, you hear the azan [the call for prayer] almost everywhere in Mauritius, you celebrate 'Id al-fitr [the festival marking the end of Ramadan], and all the chicken meat for sale in Mauritius is halal. But my cousin Asif who studied in England often had a problem with food; he had to drive a long way to eat halal food. They are cut off. Even in India, Muslims have a lot of problems and do not get good jobs. But in Mauritius we do not have these problems and most people who are qualified get a good job. So there is no reason to feel cornered and cut off.

While comparing the situation of Mauritian Muslims to Muslims in India in favourable terms, the student also rejected the rationale for the introduction of Arabic as an 'ancestral language': 
Our ancestors came from India, and we follow our traditions. And Arabic is of no use here, nobody understands it, while Urdu is rather well known - there are films, radio, and television programmes in Urdu, so those who learn Arabic lose out. The fanatic spirit of those who want Arabic and reject our traditions is also bad for us because we are a minority and need to live in harmony with all other Mauritians.

Here the student characterized those who want to reform and purify Mauritian Islamic traditions and practices as too 'fanatic' to coexist successfully with others in a society like Mauritius. He evoked the distinction between authentic, benign faith and destructive communalism. Here the defence of practices linked to the local contexts of Islamic tradition also becomes part of a wider debate about Mauritian secularism as a moral project. In the manner of their opponents, followers of the Sunnat Jamaiat claim that their vision of Islam is more authentic and represents a better way to shape good citizens capable of coexistence with others. Further, Mauritian Barelwis, like their counterparts in India and Pakistan, by no means cede the scripturalist field to their Deobandi opponents, insisting that those ritual practices labelled as backward and inauthentic by Deobandis are in fact justifiable in light of the Qur'an and the Sunna. After Friday prayers in a Sunnat Jamaiat-affiliated mosque in a suburb of Port Louis more than half of the men present left immediately while those who remained gathered closely around the imam, standing up and reciting salam. When I asked the friend who had accompanied me to the mosque why most of the worshippers had left before the salam, he replied: 'Only those who are brainwashed are against the salam, because the salam brings us closer to God via the Prophet'. An imam in a northern village also defended the legitimacy of such practices of intercession: 'All the poetry, all the nat and qasida [another poetic genre used in eulogizing saints] were already there in Arabia, they took it to India and from there to Mauritius. There was only a translation into Urdu in between'. The imam insisted that these are laudable practices linked to the 'sources' of Islam and bestowing additional benefits.

Finally, the supporters of the Barelwi tradition are suspicious about the introduction and growing popularity of Arabic in its competition with the previously established Urdu to become the ancestral language for Mauritian Muslims. They often charged that the introduction of Arabic into state schools is part of a scheme by the Hindu-dominated government to divide and weaken the Muslim community. A student claimed that 'to destroy a community, you only need to introduce a second ancestral language'. An Urdu teacher asserted that Arabic was introduced to schools to divide the Muslims, especially in electoral districts such as Port Louis and Phoenix where they are either a large group or the majority: 'The government did not allow the introduction of Sanskrit alongside Hindi for Hindus, but they introduce Arabic alongside Urdu!' He rejected such state interference in Muslim 'ancestral culture' not only because of professional and material interests, but also because he thought it undermines the 'Islamic culture' of Muslims through which their position in the nation is defined. Opting for Arabic is portrayed as motivated by financial incentives from oilrich Arab states such as Libya and Saudi Arabia, which, through the Libyan embassy and Saudi-financed World Muslim League (Rabitat al-'Alam al-Islami), initially played key roles in promoting the study of Arabic among Mauritian Muslims. Many in particular recall the activities of the Libyan embassy in the late 1970s and early 1980 os in inducing local Muslims to support the propagation of Arabic by means of material incentives at a time when poverty was still widespread. According to a retired civil servant, those calling for Arabic as an ancestral language in the context of a specific 
reformist agenda have no right to claim the cause of moral purification and uplift. On the contrary,

Arabic is just a matter of money. The Libyans offered these banquets with a lot of meat and chicken which most people could not afford at the time. There was also the hope that through Arabic one could get well-paid jobs in Saudi Arabia or Kuwait. But Urdu is much more accessible than Arabic. The consequence is that Urdu is neglected and that Muslims in Mauritius are losing their Islamic culture.

Here, this man charged the advocates of Arabic with the same moral failings - materialism and greed - that the state-sponsored cultivation of 'ancestral' religious tradition seeks to overcome.

The rejection of the position of Deobandi reformers is not framed in a defence of popular tradition, but in a discourse of Islamic learning, engaging reformist claims of superior genealogical authority on their own terms. In a publication of the government-sponsored Islamic Cultural Centre, Mawlana Shameem Ashraf Azhari, the Indian-born imam of the Jummah Mosque of Port Louis and a graduate of Al-Azhar University in Cairo, defended the centrality of Urdu for Mauritian Islam:

\footnotetext{
We can even say that Urdu has a major contribution in preserving our faith and culture on this island. The language of the Holy Qur'an is Arabic but it is through Urdu books on Islam and Urdu translations of the Holy Book that many of us have come to comprehend the Word of Allah. The valuable commentaries of great 'ulama [Islamic scholars] have also proved to be extremely useful, especially that of Aala Hazrat Imam Ahmad Raza Khan (R.A.) [the founder of the Barelwi tradition who was a very prolific writer in Urdu] ... Our grandfathers used to celebrate mawlud functions, which are part of our culture, and the nat that were recited on those occasions were mostly written in Urdu. Through such activities both our culture and faith have been preserved and the light of Islam has continued to illuminate the lives of people. ${ }^{16}$
}

While Deobandis justify the introduction of Arabic as a matter of greater genealogical authority and as a contribution to education, their opponents seek to delegitimize the study of Arabic as a matter of economic opportunism or as a ploy to divide the Muslim community. Urdu is presented by Mawlana Shameem as the living medium of Islamic tradition and as essential for the reproduction of true Islam and the moral guidance that it provides Mauritian Muslims. Promoters of Urdu who are also followers of the Sunnat Jamaiat underline the legitimacy of their position by indicating that the Mauritian government still recognizes the Sunnat Jamaiat-affiliated Jummah Mosque as representative of the Muslim community of Mauritius, despite that community's internal divisions. While government intervention in official 'Islamic culture' through the introduction of Arabic as second ancestral language has provoked considerable antagonism, a group of Urdu teachers nevertheless noted with satisfaction that on Muslim holidays such as yawm un-nabi and 'Id al-fitr the government-controlled Mauritius Broadcasting Corporation (MBC) only broadcasts on television addresses in Urdu by the imam of the Jummah Mosque while on Fridays his sermons are broadcast on MBC radio. As noted by an Urdu teacher, who admitted having been concerned about the future of his profession: 'In the 1980s we were very worried that Arabic would take over completely. But as long as the government recognizes the Jummah Mosque as our representatives we are protected from Arabic'. 
Here also, an internal debate about authenticity within an Islamic tradition is linked not only to the position of Mauritian Muslims within the nation but also to the morality of secularism. While the Deobandis and others labelled 'Tawhidis' justify their agenda of purification in terms of moral reform aimed at producing morally grounded and responsible citizens, the followers of the Sunnat Jamaiat, led by the Jummah Mosque, assert the legitimacy of their traditions by virtue of their being recognized by the Mauritian state as the main representative of Muslim 'ancestral culture'. The state thus treats the Sunnat Jama'at as a main force in shaping citizens grounded in the kind of moral values which make them withstand the negative effects of 'development' and suitable for successful coexistence with other Mauritians, providing the followers of the Sunnat Jamaiat with legitimization in what would otherwise be an internal debate about Islamic tradition'.

\section{Conclusion}

Recent writings on Mauritius have tended to describe the inter-ethnic coexistence for which the island has become well known as a result of pragmatic compromises. Thomas Eriksen, for example, has argued that a set of 'common denominators' (1998: 18) has enabled relatively successful coexistence among Mauritians. A growing sense of Mauritian nationhood is sustained by a common education system and an increasingly 'meritocratic' integration into a capitalist wage economy (Eriksen 1994). ${ }^{17}$ Here both pragmatic accommodation and a putatively intensifying Mauritian nationalism across ethnic lines have been analysed as unrelated to religious values and discourses. The emergent post-colonial Mauritian sense of nationhood is thus portrayed as entirely secular, with religious practices and values playing no role in it. Secularism, indeed, replaces religious practices and values with a 'more universalist symbolic system, namely supra-ethnic nationalism’ (Eriksen 1998: 97).

Religion promotes cultural integration; but by contrast with the Medieval Church, operating in a universe that was largely homogeneous, the religions of Mauritius represent exclusive and mutually excluding forms of integration. When it is politicized, religion thus competes directly with nationhood in this kind of society. When it is not, religious diversity is compatible with Mauritian nationalism (Eriksen 1998: 97).

Here, secularism and political religiosity are not in a dialectical tension, but perceived in terms of a zero-sum antagonism presupposing a normative liberal contrast between a problematic politicization of religion and a more benign confinement of religion to a sphere of the non-political. However, as I have tried to argue, as religion becomes part of nationhood and discourses of coexistence, religious practices and values inevitably become politicized and a focus of contestation, even in their most seemingly 'private' or 'anti-political' forms such as personal piety and moral rectitude (cf. Asad 2003: 181-201). ${ }^{18}$

The much greater emphasis placed by Mauritian state institutions on the public performance of diasporic 'ancestral cultures' centred on religious traditions as compared to those cultural forms which are portrayed as locally created suggests that those Mauritians with recognized claims on such 'ancestral cultures' with origins elsewhere are more centrally placed in a post-colonial Mauritian nation than those who lack such claims, such as the Creoles. As Mauritian nationhood cannot be neatly separated from issues of ethnic difference, the separation of Mauritian nationhood from religious values and solidarities is equally questionable, let alone the suggestion that the 
cultivation of religious traditions in the context of a conscious effort to accommodate religious diversity could be in any way depoliticized.

As I have sought to show, internal Muslim debates testify to a 'spill-over' of a politics of secularism based on a mobilization of 'ancestral' values into disputes about religious reform and authority. At the same time, it is impossible to relegate religiously based 'ancestral cultures' to a realm of the private or describe them as purely internal to the communities defined by them, since Mauritian cultural politics positions them as key components of a Mauritian nation and as guarantors of peaceful coexistence. Attributing Mauritian coexistence exclusively to a set of pragmatic arrangements and cross-ethnic commonalities underestimates the extent to which secularism constitutes a moral project, a field of values and dispositions shaping national subjects. Instead of developing an alternative language of national solidarity, the way secularism is lived as the search for equitable coexistence in an officially multi-religious polity indicates that the moral imperatives of the secular are closely articulated with the responsibilities demanded by religious tradition.

\section{NOTES}

Fieldwork in Mauritius was carried out in 1996, 1997-8 and 2003 and was supported by the University of Chicago Council for Advanced Studies in Peace and International Cooperation, the Wenner-Gren Foundation, and by a Washington University Grimm Traveling Fellowship to Asia. The University of Mauritius provided valuable help during my research and here I would especially like to thank Vinesh Hookoomsing and Shawkat Toorawa. I also thank John Bowen for his helpful comments on this article. Most of all, I am indebted to the many Mauritians without whose support and friendship my research would have been impossible.

${ }^{1}$ Of course, both diasporic and 'indigenous' cultural practices and symbols have to be understood as to a great extent locally created. My concern here is to highlight the differences in their ideological representations as direct continuations of traditions essentially imagined to be elsewhere or as uniquely particular to the island.

${ }^{2}$ For example, despite the long-standing complaints of several intellectuals (e.g. Virasawmy 1984), in stark contrast to the teaching and cultivation of the rarely used ancestral languages, the practice of Mauritian Creole receives little support and recognition by the Mauritian state.

${ }^{3}$ Although presented as a policy of 'unity in diversity', this approach to cultural citizenship has in fact exclusionist implications. This is because not all Mauritians, in particular the descendants of African and Malagasy slaves known as Creoles, have recognized claims on legitimizing 'ancestral cultures' and ancestral languages with origins outside Mauritius (Laville 2000).

${ }^{4}$ According to the constitution, Mauritians are divided into four principal 'communities': Hindus (52 per cent), Muslims (17 per cent), Sino-Mauritians (2 per cent), and the General Population (29 per cent). The General Population is defined as all Mauritians who do not belong to the three aforementioned categories. De facto these are Creoles and Franco-Mauritians, and are Christian, overwhelmingly Catholic. The General Population is thus implicitly defined as the Christian population of Mauritius of non-Chinese origin. Of all the official communities, only the small and multi-religious Sino-Mauritian community is not defined in terms of religion.

${ }^{5}$ The spectre of the destructive communalism was recently invoked by inter-ethnic violence. Following the February 1999 death under suspicious circumstances in police custody of a popular singer of Creole background, there were violent clashes between protesters and looters of largely poor Creole background and the Hindu-dominated police force. Following this first round of riots Hindu mobs attacked and in two cases burned down Creole neighbourhoods. The riots left four people dead and caused direct and indirect damage estimated at $\$ 50$ million.

${ }^{6}$ The National Urdu Institute, 2oth Anniversary 1990, Souvenir Magazine, p. 3. Port Louis, the National Urdu Institute.

${ }^{7}$ Second World Urdu Conference, Republic of Mauritius, 2-6 August 2003, Souvenir Magazine, p. 6. Port Louis, the National Urdu Institute/Urdu-Speaking Union.

${ }^{8}$ Ramayana Centre in Mauritius, Organizer (New Delhi), 8 September 2002.

${ }^{9}$ Ibid. 
10 'SAJ and values of Ramayana: from then to now and beyond', Mauritius Times, 23 August 2002. Sir Anerood Jugnauth is reported to have used Hindi for this statement: Rajniti men ramayan mera sabse bara adarsh rahi hai.

${ }^{11}$ Bhakti: a devotional path in Hindu tradition characterized by emotional attraction to a personal God. Invoking bhakti in this context emphasizes absolute devotion and sacrifice for a higher goal. Shakti (Sanskrit: 'power' or 'energy'): the absolute power and energy associated with the divine mother in Hindu tradition.

${ }^{12}$ Certainly, Mauritians of other communities did not all agree with this reading of Jugnauth's recourse to Hindu tradition to describe the way he had led the country for a total of sixteen years. See 'Séculier vs. laïque - Le Ramayana, SAJ et la laïcité' in the daily L'Express, 30 November 2004.

${ }^{13}$ Sunnis are the vast majority among Mauritian Muslims. There are also two small communities of Shic ites of Gujarati background on the island, Must'ali Ismaelis (Bohra) and Twelver Shi'ites (Khoja Ithna 'Ashari). Further, there are also Ahmadis, whose claim to be Muslims is recognized by the constitution and by nonMuslim Mauritians in general, while often denied by other Mauritian Muslims. The Sunnat Jamaiat is also linked to the Sufi order of the Qadriyya, to which the Kutchi Memons are closely attached (Jahangeer-Chojoo 1997: 222-6).

${ }^{14}$ On the Tablighi Jamaiat, see Metcalf (1993).

${ }^{15}$ In Mauritius, this purist form of Islam is often identified by the term tawhid, oneness (of God), which refers to the Islam of Deobandi-affiliated reformists as well as that of persons, such as Imam Beharry, who promote a more Saudi-orientated reformism.

${ }^{16}$ Urdu Week, 'Urdu khidmat-i Islam men - Urdu in the service of Islam', 6-13 April 1996. Souvenir Magazine, p. 13. Port Louis, Islamic Cultural Centre.

${ }^{17}$ One might argue that these conditions are also found in multi-ethnic Indian urban environments such as Mumbai which are characterized by high levels of ethnic tension and violence. In fact, Nandy (1990, 1998) has targeted exactly those commonalities as responsible for the rise of violent Hindu nationalism.

${ }^{18}$ See also Mahmood (2005: 34-5, 152) on how the seemingly apolitical practices of piety of the Egyptian women's mosque movement do in fact constitute new forms of political agency.

\section{REFERENCES}

AsAD, T. 2003. Formations of the secular: Christianity, Islam, modernity. Stanford: University Press.

Baubérot, J. 2000. Histoire de la laïcité française. Paris: Presses Universitaires de France.

Carter, M. 1995. Servants, sirdars, settlers: Indians in Mauritius 1834-1874. Delhi: Oxford University Press.

Chatterjee, P. 1995. Religious minorities and the secular state: notes on an Indian impasse. Public Culture 8, 11-39.

EISENlohr, P. in press. Little India: diaspora, time and ethnolinguistic belonging in Hindu Mauritius. Berkeley: University of California Press.

Eriksen, T.H. 1994. Nationalism, Mauritian style: cultural unity and ethnic diversity. Comparative Studies in Society and History 36, 549-74.

1998. Common denominators: ethnicity, nation-building and compromise in Mauritius. Oxford: Berg.

Foucault, M. 1991. Governmentality. In The Foucault effect: studies in governmentality (eds) G. Burchell,

C. Gordon \& P. Miller, 87-104. Chicago: University Press.

Göle, N. 1997. The gendered nature of the public sphere. Public Culture 10, 61-81.

Hansen, T.B. 1999. The saffron wave: democracy and Hindu nationalism. Princeton: University Press. 200o. Predicaments of secularism: Muslim identities and politics in Mumbai. Journal of the Royal Anthropological Institute (N.S.) 6, 255-72.

Hollup, O. 1996. Islamic revivalism and political opposition among minority Muslims in Mauritius. Ethnology 35, 285-300.

Jahangeer-Chojoo, A. 1997. La communauté musulmane de Port Louis: une étude de géographie sociale. Thèse de doctorat, Université Michel de Montaigne, Bordeaux III.

Kalla, A.C. 1987. The Gujarati merchants in Mauritius c.1850-1900. Journal of Mauritian Studies 2: 1, 45-65.

Laville, R. 2000. In the politics of the rainbow: Creoles and civil society in Mauritius. Journal of Contemporary African Studies 18, 277-94.

Manmood, S. 2005. Politics of piety: the Islamic revival and the feminist subject. Princeton: University Press. Metcalf, B.D. 1993. Living Hadith in the Tablīghī Jamā'at. Journal of Asian Studies 52, 584-608.

Nandy, A. 1990. The politics of secularism and the recovery of religious tolerance. In Mirrors of violence (ed.) V. Das, 69-93. Delhi: Oxford University Press. 


\title{
412 PATRICK EISENLOHR
}

1998. The twilight of certitudes: Hindu nationalism and other masks of deculturation. Postcolonial Studies 1, 283-98.

Navaro-Yashin, Y. 2002. Faces of the state: secularism and public life in Turkey. Princeton: University Press.

Parsuraman, A. 1988. From ancestral cultures to national culture: Mauritius. Moka: Mahatma Gandhi Institute Press.

SAnyal, U. 1996. Devotional Islam and politics in British India: Ahmad Riza Khan Barelwi and his movement (1870-1920). Oxford: University Press.

Virasawmy, D. 1984. Le système éducatif mauricien: problèmes et possibilités. Études Créoles 7: 1-2, 116-25.

Woolard, K.A. \& B. Schieffelin 1994. Language ideology. Annual Review of Anthropology 23, 55-82.

\section{Politique de la diaspora et moralité du sécularisme : les identités musulmanes et l'autorité islamique à Maurice}

\begin{abstract}
Résumé
Les travaux antérieurs sur la coexistence interethnique à Maurice présentaient le sécularisme comme le seul lieu possible de l'unité nationale, tout en décrivant celle-ci comme clairement séparée des traditions religieuses. L'auteur se concentre pour sa part sur la compréhension du sécularisme chez les musulmans mauriciens dans le contexte d'une politique de "cultures ancestrales » diasporiques, et analyse le sécularisme comme un domaine de la moralité indissociable des questions de réforme religieuse et d'authenticité. La discussion du matériel ethnographique obtenu à Maurice suggère que l'opposition entre séculaire et religieux doit être abordée comme une tension productive et non comme une antinomie libérale.
\end{abstract}

Patrick Eisenlohr is Assistant Professor of Anthropology at Washington University in St Louis. He received a Ph.D. from the University of Chicago in 2001 and an MA from Karl-Ruprechts Universität Heidelberg in 1995. His research interests are linguistic anthropology, religion and electronic media, pluralism and cultural citizenship, the study of diasporas, as well as South Asian Islam and Hinduism.

Department of Anthropology, Washington University, One Brookings Drive, Campus Box 1114, St Louis, MO 63130-4899, USA. peisenlo@wustl.edu 